\title{
Patients Satisfaction towards Aravind Eye Care Hospital in Madurai City
}

\section{OPEN ACCESS}

Manuscript ID:

ASH-2021-09014039

Volume: 9

Issue: 1

Month: July

Year: 2021

P-ISSN: 2321-788X

E-ISSN: 2582-0397

Received: 18.04.2021

Accepted: 20.05.2021

Published: 01.07.2021

Citation:

Parimala, M., and S.

Singtha. "Patients

Satisfaction towards

Aravind Eye Care Hospital in Madurai City." Shanlax International Journal of Arts, Science and Humanities, vol. 9, no. 1, 2021, pp. 147-153.

DOI:

https://doi.org/10.34293/ sijash.v9i1.4039

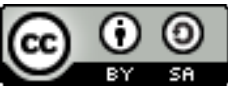

This work is licensed under a Creative Commons Attribution-ShareAlike 4.0 International License

\section{Parimala}

Associate Professor, Department of Commerce

Lady Doak College,Madurai, Tamil Nadu, India

\section{S. Signtha}

Department of Commerce, Lady Doak College, Madurai, Tamil Nadu, India

\section{Abstract}

Customers may decide to select the service or product based on the quality which has been considered as a strategic benefit for any business to gain and sustain in the market for a longer time. Products quality can be measured but the services qualities are not tangible to measure, it is depends upon the perceptions and exceptions of the customers. Perceptions and expectations of patients are considered to be the major indicator to assess the service quality of healthcare organization, because it is also highly competitive. In today's dynamic business environment from the firm's point of view it is about to build and sustain a strong relationship with their customers by understanding the ingredients of customer satisfaction and Hospitals sectors also need to do this. Hospitals are also classified on the basis of services provided. The various types of hospitals like Dental Hospitals, Eye Care Hospitals, Fertility Care Hospitals, Cancer Hospitals, Children Hospitals, Maternity Hospitals, Orthopedic Hospitals etc., among the various hospitals, eye care hospitals play a vital role. They provide treatments for various eye related problems. One of the big eye care hospital in Madurai is Aravind Eye Care Hospitals. The present generations are using technology in various forms to complete their task, which may lead to face some eye problems like Low Vision, Eye Irritation, Eye strain and many more. Need of Eye Care Hospital plays important role to overcome such problems. The present study focused on the patients' satisfaction and perception towards Aravind Eye Care Hospital.

Keywords: Aravind Eye Care Hospital, Customer satisfaction, Eye problem, Perceptions, Technology, Young generations

\section{Introduction}

In India, Aravind Eye Care Hospitals is a hospital chain. In the year of 1976, Dr. Dr.Govindappa Venkataswamy (popularly known as Dr. V) was established the Aravind Eye Care Hospital in Madurai, Tamil Nadu in 1976. It has had a great impact to eradicate the cataract eye problem related to blindness in India, grown into a network. By the year 2012, nearly 32 million patients had treatments and 4 million surgeries were done by Aravind Eye Care Hospitals. Across the world, Aravind Eye Care hospitals much-admired and become a focus for numerous cases studied. The founder of the hospital has a vision to eradicate the eye problems in India. The Hospital began performing surgeries on a large scale with treatment being free or heavily subsidized for the poor cross subsidized by the paying patients. Aravind Eye Care Hospital established an outreach program wherein Doctors reach out to remote villages to conduct Eye Camps, sometimes in association with various organizations.

\section{Statement of the Problem}

As the Eye Care industry shifts towards managed competition and a modern era of Eye Care, information for positioning an entire organization to meet patient requirements effectively will become growingly essential. 
Hospital industry has started witnessing cutthroat competition in recent years. Quality of service has also been shown to be an important driver of patient satisfaction both from theoretical point of view and empirically substantiated in a variety of industries including service industries.

So the research has been carried out to find the factors influencing the patients to select the Hospital, to understand patients' dissatisfaction and to determine the problems wherein the hospitals need to focus and to strengthen their patient relationship management practices.

\section{Scope of the Study}

Now-a-days everyone using the Smart Phone and Laptop or Computer for a long time because of that Eye are much affected. So the researchers have chosen to study the perception and level of patients' satisfaction and loyalty towards services offered by Aravind Eye Care Hospital. The study has been undertaken from the point of view of the respondents of Aravind Eye Care Hospital in Madurai.

\section{Objectives of the Study}

- To determine the Patients' perception on the services of Aravind Eye Care Hospital

- To know the level of patient's satisfaction towards the Aravind Eye Care Hospital.

- To get suggestions from patients about the treatment and consultation process that they have undergone in Aravind Eye Care hospital.

- To focus on the expectations of the patient satisfaction on Aravind Eye Care Hospital.

\section{Review of Literature}

Alaloola and Albedaiwi (2008) conducted research survey to find patient satisfaction. Based on the analysis it was conclude that patients' had satisfaction with the room facilities and respectful staff. Patients were significantly dissatisfied with not explaining procedures and physicians not introducing themselves.

Alhashem, et al., (2011) in this article that the researcher measured the quality of patient satisfaction as one of the most important indicators. The objective of the study to find out the factors which are affect the patients satisfaction at primary health care clinics. The questionnaires were distributed in primary healthcare clinics that represent all health care regions. A total of 400 completed questionnaires, out of 500, were returned resulting in a response rate of 85.2 percent. The $87 \%$ of the patients responded that the time for communication between physician and patient was not enough. $79 \%$ of the surveyed patients said they would go to the emergency room of the hospital in future if needed instead of going to the primary care clinic. Regarding the quality of the communication relationship between physician and patients most of the respondents responded negatively.

Arun Kumar, et al., (2012) in his study entitled "Service Quality at Hospital - A Study of Apollo Hospital in Mysore". The objective is to examine the service quality influence on patient loyalty towards Apollo hospital of Mysore. It can be measured based on some dimensions named as SERVQUAL, in which four dimensions like responsiveness, empathy, reliability and tangible were considered. Finally the study concluded that all such dimensions are optimistically related to patient's loyalty.

\section{Methodology of the Study}

Research Design: Descriptive and Analytical Research Design.

\section{Determination of Sample Size}

Sample Size: 100

Sampling Technique: Convenient sampling technique

\section{Sources of Data}

Primary Source: Structured questionnaire was used to collect the data. Simple Percentage Method, Garrett Ranking Method was adopted to measure the responses.

Secondary Data: Official website, Journals

Method of Data Collection: Google form

\section{Framework of Analysis}

Inferential Statistics: Chi-Square, Correlation, ANOVA and t-Test were adopted to measure the responses. 


\begin{tabular}{|c|c|c|}
\hline \multicolumn{3}{|c|}{ Hypothesis } \\
\hline $\begin{array}{l}\mathrm{HO} / \\
\mathrm{H} 1\end{array}$ & Description & $\begin{array}{c}\text { Testing } \\
\text { Methods }\end{array}$ \\
\hline HO & $\begin{array}{l}\text { There is no significant } \\
\text { relationship between age group } \\
\text { of the respondents and level of } \\
\text { perception. }\end{array}$ & \multirow[t]{2}{*}{ Chi-square } \\
\hline H1 & $\begin{array}{l}\text { There is significant relationship } \\
\text { between age group of the } \\
\text { respondents and level of } \\
\text { perception. }\end{array}$ & \\
\hline HO & $\begin{array}{l}\text { There is no significant difference } \\
\text { between monthly incomes with } \\
\text { regard to convenient visit to } \\
\text { Aravind Eye Care Hospital. }\end{array}$ & \multirow{2}{*}{ Correlation } \\
\hline H1 & $\begin{array}{l}\text { There is significant difference } \\
\text { between monthly incomes with } \\
\text { regard to visit to Aravind Eye } \\
\text { Care Hospital. }\end{array}$ & \\
\hline HO & $\begin{array}{l}\text { There is no significant difference } \\
\text { between visits with regard to } \\
\text { hospital location. }\end{array}$ & \multirow{2}{*}{$\begin{array}{l}\text { One way } \\
\text { ANOVA }\end{array}$} \\
\hline H1 & $\begin{array}{l}\text { There is significant difference } \\
\text { between visits with regard to c } \\
\text { hospital location. }\end{array}$ & \\
\hline HO & $\begin{array}{l}\text { There is no significant difference } \\
\text { between purchases of opticals } \\
\text { with regard to price of opticals. }\end{array}$ & \multirow{2}{*}{ t-test } \\
\hline H1 & $\begin{array}{l}\text { There is significant difference } \\
\text { between purchases of opticals } \\
\text { with regard to price of opticals. }\end{array}$ & \\
\hline
\end{tabular}

\section{Limitations of the Study}

- In the study area, there are other Eye Care hospitals, the study is focused only of Aravind Eye Care Hospital and it is not applicable for Universal Level.

- Patient satisfaction attitude behaviour will change anytime and cannot expect to be stable all the time.

- If we meet the same respondents again but cannot expect the same opinion from the respondents.

\section{Analysis}

Percentage Analysis

\begin{tabular}{|c|c|c|}
\hline Particulars & Class Intervals & $\%$ \\
\hline \multirow{3}{*}{ Age } & 10 to 20 & 14 \\
\hline & 20 to 40 & 79 \\
\hline & 40 and above & 7 \\
\hline \multirow{4}{*}{$\begin{array}{l}\text { Educational } \\
\text { Qualification }\end{array}$} & PG & 30 \\
\hline & UG & 61 \\
\hline & Diploma & 5 \\
\hline & Upto XII & 4 \\
\hline \multirow{2}{*}{ Marital Status } & Married & 25 \\
\hline & Unmarried & 75 \\
\hline \multirow{2}{*}{ Family Type } & Nuclear Family & 27 \\
\hline & Joint Family & 73 \\
\hline \multirow{5}{*}{ Monthly Income } & Below Rs 10000 & 11 \\
\hline & Rs $10000-20000$ & 21 \\
\hline & Rs $20000-30000$ & 24 \\
\hline & Rs 30000 - 40000 & 15 \\
\hline & Rs. 40000 and above & 29 \\
\hline \multirow{9}{*}{$\begin{array}{l}\text { Employment } \\
\text { Status }\end{array}$} & Employed & 2 \\
\hline & Housewives & 3 \\
\hline & IT Professionals & 3 \\
\hline & Professor in College & 1 \\
\hline & Retired & 3 \\
\hline & Self Employed & 21 \\
\hline & Software Engineers & 3 \\
\hline & Students & 46 \\
\hline & Unemployed & 18 \\
\hline
\end{tabular}

Source: Primary Data

About Aravind Eye Care Hospital

\begin{tabular}{|c|l|c|}
\hline Particulars & \multicolumn{1}{|c|}{ Class Intervals } & \% \\
\hline \multirow{3}{*}{$\begin{array}{c}\text { Information } \\
\text { about }\end{array}$} & Advertisement & 17 \\
\cline { 2 - 3 } $\begin{array}{c}\text { Aravind Eye } \\
\text { Care Hospital }\end{array}$ & Family And Friends & 68 \\
\cline { 2 - 3 } & Magazines & 3 \\
\cline { 2 - 3 } & Neighbours & 12 \\
\hline \multirow{4}{*}{$\begin{array}{c}\text { Purpose of } \\
\text { Visit }\end{array}$} & Eye Irritation & 31 \\
\cline { 2 - 3 } & Regular Check up & 44 \\
\cline { 2 - 3 } & Headache & 1 \\
\cline { 2 - 3 } & Others (surgery, eye problem, etc) & 24 \\
\hline \multirow{2}{*}{$\begin{array}{c}\text { Frequency } \\
\text { of Visit on }\end{array}$} & $>6$ Months & 29 \\
\cline { 2 - 3 } Monthly And & 1 to 3 Years & 26 \\
\cline { 2 - 3 } Year Basis & 3 to 5 Years & 17 \\
\cline { 2 - 3 } & Above 5 Years & 28 \\
\hline
\end{tabular}




\begin{tabular}{|c|l|c|}
\hline \multirow{4}{*}{$\begin{array}{c}\text { Navigate } \\
\text { to Hospital }\end{array}$} & Difficult & 6 \\
\cline { 2 - 3 } Treatment & Easy & 49 \\
\cline { 2 - 3 } & Neutral & 31 \\
\cline { 2 - 3 } & Very Difficult & 1 \\
\cline { 2 - 3 } & Very Easy & 13 \\
\hline \multirow{4}{*}{$\begin{array}{c}\text { Reason to } \\
\text { Visit }\end{array}$} & Blurred or Double Vision & 34 \\
\cline { 2 - 3 } & Checkup & 1 \\
\cline { 2 - 3 } & Eye Disease & 12 \\
\cline { 2 - 3 } & Eye Pain & 20 \\
\cline { 2 - 3 } & Eye Strain or Headache & 32 \\
\cline { 2 - 3 } & Redness In Eyes & 1 \\
\hline
\end{tabular}

Source: Computed Data

\section{Chi-Square Analysis}

Age and Level of Perception

\begin{tabular}{|c|c|}
\hline \multicolumn{2}{|c|}{ Aravind Eye Care Hospital } \\
\hline Pearson Chi Square Value & 0.011 \\
\hline Remarks & Rejected \\
\hline
\end{tabular}

Source: Computed Data

From table, it is inferred that the $\mathrm{P}$ value $(0.011)$ is more than 0.010, the null hypothesis is rejected at $5 \%$ level of significance. So there is significant difference between Age and Level of Perception of different sectors in Aravind Eye Care Hospital.

In the below table monthly income and number of time visit to hospital were positively correlated at 0.019 , and the $\mathrm{P}$ value is 0.854 , so it is determined that "There is no significant relationship between the monthly income of respondents and Level of Perception on convenient location of Aravind Eye Care Hospital" is Accepted.

\section{Correlation}

Monthly Income and Visit to Hospital

\begin{tabular}{|c|c|c|}
\hline Particulars & $\begin{array}{r}\text { Monthly Income and Visit } \\
\text { to Hospital }\end{array}$ \\
\hline Pearson Correlation & 1 & 0.019 \\
\hline Sig. (2-tailed) & - & 0.854 \\
\hline N & \multicolumn{2}{|c|}{100} \\
\hline
\end{tabular}

Source: Computed Data

\section{One Way ANOVA}

Monthly Visit to Hospital And Location of the Hospital

\begin{tabular}{|l|c|c|c|c|c|}
\hline Particulars & $\begin{array}{c}\text { Sum of } \\
\text { Squares }\end{array}$ & d.f & $\begin{array}{c}\text { Mean } \\
\text { square }\end{array}$ & F & Sig. \\
\hline $\begin{array}{l}\text { Between } \\
\text { groups }\end{array}$ & 5.940 & 3 & 1.980 & \multirow{2}{*}{1.432} & 0.238 \\
\hline $\begin{array}{l}\text { Within } \\
\text { groups }\end{array}$ & 132.700 & 96 & 1.382 & & \\
\hline \multicolumn{1}{|c|}{ Total } & 138.640 & 99 & & & \\
\hline
\end{tabular}

Source: Computed Data

It is inferred that $P$ value $(0.238)$ is less than 0.050 , the null hypothesis is rejected. Thus, it is concluded that there is significant difference monthly visit to hospital with regard to hospital location.

\section{t-TEST}

Purchase of Opticals and Price of Opticals

\begin{tabular}{|c|c|c|c|c|c|c|c|c|}
\hline \multirow{3}{*}{ Particulars } & \multicolumn{5}{|c|}{ Paired Differences } & \multirow{3}{*}{$\mathbf{t}$} & \multirow{3}{*}{ df } & \multirow{3}{*}{$\begin{array}{c}\text { Sig. } \\
(2- \\
\text { tailed) }\end{array}$} \\
\hline & \multirow[t]{2}{*}{ Mean } & \multirow{2}{*}{$\begin{array}{c}\text { Std. } \\
\text { Deviation }\end{array}$} & \multirow{2}{*}{$\begin{array}{l}\text { Std. Error } \\
\text { Mean }\end{array}$} & \multicolumn{2}{|c|}{$\begin{array}{c}95 \% \text { of Confidence } \\
\text { Interval of the Difference }\end{array}$} & & & \\
\hline & & & & Lower & Upper & & & \\
\hline $\begin{array}{l}\text { Purchase of Opticals } \\
\text { and Price of Opticals }\end{array}$ & 0.4100 & 0.7667 & 0.0767 & 0.5621 & 0.2579 & 5.348 & 99 & 0.000 \\
\hline
\end{tabular}

Source: computed data

$\mathrm{P}$ value (0.000) is less than $0.10, \mathrm{t}$ is determined purchase of opticals with regard to price of opticals. that there is highly significant difference between 


\section{Likert Scaling}

\section{Preference in Hospital Facilities}

\begin{tabular}{|c|c|c|c|c|c|c|}
\hline Hospital Facilities & $\mathbf{N}$ & Minimum & Maximum & Mean & SD & Rank \\
\hline Seating Arrangements & \multirow{9}{*}{100} & \multirow{9}{*}{1.0} & \multirow{2}{*}{4.0} & 1.990 & 0.6889 & IX \\
\hline Cleanliness & & & & 1.970 & 0.8699 & VIII \\
\hline Toilet Facilities & & & 5.0 & 2.230 & 0.8391 & III \\
\hline Drinking Water Facility & & & 4.0 & 2.120 & 0.8794 & VI \\
\hline Sanitized Properly & & & 5.0 & 2.110 & 0.9089 & VII \\
\hline Fans and Lighting & & & 4.0 & 2.190 & 0.9067 & V \\
\hline Lunch Area Facility & & & \multirow{3}{*}{5.0} & 2.290 & 0.8077 & I \\
\hline Comfort of Room includes Bed, Towels, and so on & & & & 2.240 & 0.7766 & II \\
\hline Optical Shop Facility & & & & 2.220 & 0.9490 & IV \\
\hline
\end{tabular}

Source: computed data

Mean Factor 2.290 for Lunch Area Facility Rank and 2.230 for Toilet Facility is given as Third is given as First Rank, 2.240 for Comfort of room Rank depends upon the opinion.

includes bed, towels, and so on is given as Second

Preference in Food Area Facilities

\begin{tabular}{|c|c|c|c|c|c|c|}
\hline Food Area Facilities & $\mathbf{N}$ & Minimum & Maximum & Mean & SD & Rank \\
\hline Hospital food has been good & \multirow{8}{*}{100} & \multirow{8}{*}{1.0} & \multirow{2}{*}{4.0} & 2.140 & 0.9089 & IV \\
\hline Dishes and utensils are chipped and stained & & & & 2.190 & 0.9067 & III \\
\hline Staff who deliver meal are neat and clean & & & \multirow{2}{*}{5.0} & 2.230 & 0.7543 & II \\
\hline Hospital smells stop me from having meal & & & & 1.990 & 0.9789 & VII \\
\hline Cold drinks and hot drinks are just the right temperature & & & \multirow{2}{*}{4.0} & 1.970 & 0.8856 & VIII \\
\hline Vegetables are cooked properly & & & & 2.260 & 0.8765 & $\mathrm{I}$ \\
\hline Meals tastes good & & & \multirow{2}{*}{5.0} & 2.120 & 0.9876 & $\mathrm{~V}$ \\
\hline Receive enough food & & & & 2.110 & 0.8077 & VI \\
\hline
\end{tabular}

Source: Computed data

Mean Factor 2.260 for Vegetables are cooked Rank and 2.190 for Dishes and utensils are chipped properly is given as First Rank, 2.230 for Staff and stained is given as Third Rank depends upon the deliver meal are neat and clean is given as Second opinion.

\section{Preference in Nurse and Doctor Facilities}

\begin{tabular}{|c|c|c|c|c|c|c|}
\hline Doctor And Nurse Facilities & $\mathbf{N}$ & Minimum & Maximum & Mean & SD & Rank \\
\hline Friendliness and courtesy of the receptionist & \multirow{8}{*}{100} & \multirow{8}{*}{1.0} & 4.0 & 2.260 & 0.8765 & I \\
\hline Caring concern of nurses/medical assistants & & & \multirow{2}{*}{5.0} & 2.120 & 0.9876 & III \\
\hline Helpfulness of the attender who assist with billing & & & & 2.110 & 0.8077 & IV \\
\hline Are nurses being friendly and informative. & & & \multirow{4}{*}{4.0} & 1.120 & 0.9809 & VII \\
\hline Doctors are available at the right time & & & & 1.110 & 0.9087 & VIII \\
\hline $\begin{array}{l}\text { Doctors are good about explaining the reason for } \\
\text { medical tests }\end{array}$ & & & & 1.190 & 0.7658 & V \\
\hline Time that the doctor spent with you & & & & 2.230 & 0.9870 & II \\
\hline The doctor is very careful during treatment/checkups & & & 5.0 & 1.130 & 0.7890 & VI \\
\hline
\end{tabular}

Source: Computed Data 
Mean factor 2.260 for The friendliness and courtesy of the receptionist is given as First Rank, for factor 2.230 time that the doctor spent with you is given as Second Rank and for factor 2.120 the caring concern of nurses/medical assistants is given as Third Rank depends upon the opinion.

\section{Preference in Hospitability Services}

\begin{tabular}{|c|c|c|c|c|c|c|}
\hline Hospitability Services & $\mathbf{N}$ & Minimum & Maximum & Mean & SD & Rank \\
\hline Ease to make appointment by phone & \multirow{7}{*}{100} & \multirow{7}{*}{1.2} & \multirow[b]{2}{*}{4.0} & 1.990 & 0.7889 & $\mathrm{VI}$ \\
\hline $\begin{array}{l}\text { Appointment available within a reasonable amount of } \\
\text { time }\end{array}$ & & & & 1.970 & 0.6699 & VII \\
\hline The efficiency of check-in-process & & & 5.0 & 2.230 & 0.6791 & II \\
\hline Waiting time in the reception area & & & 4.0 & 2.140 & 0.8794 & V \\
\hline Waiting time in the testing room & & & 5.0 & 2.150 & 0.8989 & IV \\
\hline Ease of getting necessary information when you needed & & & 4.0 & 2.190 & 0.9067 & III \\
\hline I feel comfort to discuss the problems with the doctors & & & 5.0 & 2.290 & 0.8077 & I \\
\hline
\end{tabular}

Source: Computed Data

Mean factor 2.290 for feel comfort to discuss the problems with the doctors. is given as First Rank, for factor 2.230. The efficiency of check-in-process is given as Second Rank and for factor 2.190. Ease of getting necessary information when you needed is given as Third Rank depends upon the opinion.

\section{Findings}

- $14 \%$ of respondents are at the age of 10 to 20 , $79 \%$ of respondents are at the age of 20 to 40 and $7 \%$ of respondents are at the age group of 40 and above.

- $5 \%$ of respondents done Diploma, $30 \%$ of respondents has completed Post Graduation, 4\% of respondents are from School Level and 61\% of respondents has completed Under Graduation.

- $75 \%$ of respondents are Unmarried and 25\% are Married.

- $\quad 27 \%$ of respondents are Joint Family and $72 \%$ of respondents are Nuclear Families.

- $11 \%$ of respondents Income Level are below Rs $10000,21 \%$ of respondents Income Level are Rs 10000 to Rs 20000, 24\% of respondents Income Level are Rs 20000 to Rs 30000, 29\% of respondents Income Level are Rs 30000 to Rs 40000 and Rs 40000 and above.

- $46 \%$ of respondents are Student, $21 \%$ of respondents are Self Employed, 2\% are Employed, 3\% of respondents are Retired Person and $12 \%$ respondents belong to other category.
- $17 \%$ of respondents information about Aravind Eye Care Hospital from Advertisements, $68 \%$ of respondents hears from Family and Friends,3\% of respondents hears from Magazines and 32\% of respondents hears from Neighbors are $32 \%$.

- $31 \%$ of respondents' purpose of visit to hospital for Eye Irritation, 44\% for Regular Checkup, 1\% for Headache and $24 \%$ of respondents belongs to other category.

- $29 \%$ of respondents visit less than 6 months, $26 \%$ of respondents visit minimum 1 year less than 3 years, $17 \%$ of respondents visit minimum 3 years but less than 5 years and $28 \%$ are visiting for more than 5 years.

- $6 \%$ of respondents felt difficult to navigate, $49 \%$ of respondents say easy to navigate, $31 \%$ of respondents say neutral, $1 \%$ of respondent felt very difficult and $13 \%$ of respondents felt very easy to navigate.

- $34 \%$ of respondents first time reason is for Blurred, $1 \%$ of respondents for Checkup, $12 \%$ of respondents for Eye Disease, $32 \%$ of respondents for Eye Strain or Headache and 1\% of respondents for Redness in eyes.

- $\quad 95 \%$ of respondents said No to problem faced during treatment/checkup and $5 \%$ of respondents said Yes.

- $86 \%$ of respondents have not done operations through Eye Campus conducted by Aravind Eye Care Hospital and 14\% of respondents have done operations. 


\section{Suggestions}

- The availability of Doctors in Retina ward should be increased because the patients have to wait for more than 2 hours for just 5 minutes checkup.

- In Aravind Eye Care Hospital, the least factor to influence the Patient in selecting the Hospital is Response like Reception, nurse and doctor responses should be quick in answering to the needs of the Patients.

- Overall Aravind Eye Care Hospital has a Satisfied Patients, Aravind, few are dissatisfied about Preference on Hospital Facilities and Services and Hospital Facilities. The Hospital should understand by knowing their Patients expectation in order to increase the Level of satisfaction.

\section{Conclusion}

Patient Satisfaction is an increasing important issue both in evaluation and shaping of Eye Care, it should be carried out routinely in all aspects of Eye Care to improve the quality of Services. Patient attending Aravind Eye Care Hospital are responsible for spreading the good image of the Hospital and equally important for hospital management to Satisfy Patients. The study concluded that the Aravind Eye Care Hospital should concentrate more on patients satisfaction in hospital facility services like drinking water facility, fans and lightning facility and so on should be satisfied more.

\section{References}

Alaloola, Nesreen A., and Waleed A. Albedaiwi. "Patient satisfaction in a Riyadh Tertiary Care Centre." International Journal of Health Care Quality Assurance, vol. 21, no. 7, 2008.

Aravind Eye Care System, https://aravind.org.

Alhashem, Abdul Majeed, et al. "Factors Influencing Patient Satisfaction in Primary Healthcare Clinics in Kuwait." International Journal of Health Care Quality Assurance, vol. 24, no. 3, 2011, pp. 249-262.

Arun Kumar, G., et al. "Service Quality at Hospital A Study of Apollo Hospital in Mysore." IOSR Journal of Business and Management, vol. 4, no. 1, 2012, pp. 1-7.

Dave, Darshana R., and Reena Dave. "A Study on Service Quality and Customer Satisfaction of Selected Private hospitals of Vadodara City." Pacific Business Review International, vol. 6, no. 11, 2014.

Gupta, S.P. Statistical Methods. Sultan Chand Publications, 2014.

Hoşgör, Haydar. "The Experience of Turkey and Green Hospital Concept." Journal of Health Science and Profession, 2014.

https://medsurgeindia.com/hospital/aravind-eyehospital-madurai/

Karmali, Naazneen. “Aravind Eye Care's Vision for India." Forbes, 2010.

Kothari, C.R. Research Methodology: Methods \& Techniques. New Age International, 2004.

Lim, Puay Cheng, and Nelson K.H. Tang. "The Development of a Model for Total Quality Healthcare." Managing Service Quality, vol. 10, no. 2, 2000, pp. 103-111.

Sivadas, Eugene, and Jamie L. Baker-Prewitt. "An Examination of the Relationship between Service Quality, Customer Satisfaction, and Store Loyalty." International Journal of Retail \& Distribution Management, vol. 28, no. 2, 2000, pp. 73-82.

Sudhan, Anand. "Patient Satisfaction Regarding Eye Care Services at Tertiary Hospital of Central India." Oman Journal of Ophthalmology, vol. 4, 2011, pp. 73-76.

Yavas, Ugur, and Donald J. Shemwell. "Modified Importance-Performance Analysis: An Application to Hospitals." International Journal of Health Care Quality Assurance, vol. 14, no. 3, 2001, pp. 104-110.

\section{Author Details}

M. Parimala, Associate Professor, Department of Commerce, Lady Doak College, Madurai, Tamil Nadu, India, Email ID: parimala@ldc.edu.in

S. Snigtha, PG Student, Department of Commerce, Lady Doak College, Madurai, Tamil Nadu, India 